\title{
Relationship between Personality Traits and Counterproductive Work Behaviors
}

\author{
Mônica Freitas Ferreira - Universidade Federal de Minas Gerais, Belo Horizonte, Brasi \\ Elizabeth do Nascimento - Universidade Federal de Minas Gerais, Belo Horizonte, Brasil
}

\begin{abstract}
Resumo
Acompanhando o crescente interesse em identificar se traços de personalidade estão associados com a propensão para engajar em comportamentos contraproducentes no trabalho (CCTs), o objetivo deste estudo foi investigar a relação entre traços de personalidade segundo o modelo dos cinco grandes fatores (CGF) e CCTs. Participaram do estudo 381 trabalhadores, com diferentes níveis socioeconômicos e de escolaridade, de organizações públicas e privadas, provenientes de duas regiões do país. Os fatores amabilidade, conscienciosidade e neuroticismo apresentaram correlações estatisticamente significativas com três dimensiones de CCT. Análises de regressão linear revelaram que todos os cinco traços de personalidade contribuíram para a predição das dimensões de CCT. Os resultados são discutidos à luz da literatura internacional.

Palavras-chave: desempenho no trabalho, traços de personalidade, cinco grandes fatores
\end{abstract}

\section{Relação entre os Fatores de Personalidade e Comportamentos Contraproducentes no Trabalho}

\begin{abstract}
Following the growing interest in identifying whether personality traits are associated with employee's inclination toward counterproductive work behavior (CWB), the objective of this study was to investigate the relationship between personality traits based on the five-factor model with CWB. Study participants were 381 workers from different socioeconomic and educational levels in public and private organizations, from two Brazilian regions. Agreeableness, conscientiousness and neuroticism factors had statistically significant associations with three CWB dimensions. Linear regression analysis revealed all five personality traits contributed to prediction of CWB dimensions. These findings are discussed in light of international literature.

Keywords: job performance, personality traits, big five
\end{abstract}

Relación entre Rasgos de Personalidad y Comportamientos Contraproducentes en el Trabajo

\begin{abstract}
Resumen
Siguiendo el creciente interés en identificar si los rasgos de personalidad están asociados con la propensión a participar en comportamientos contraproducentes en el trabajo (CCTs), el objetivo de este estudio fue investigar la relación entre rasgos de personalidad según el modelo de los cinco grandes factores (CGF) y CCTs. Los participantes del estudio fueron 381 trabajadores, con diferentes niveles socioeconómicos y educativos, de organizaciones públicas y privadas, provenientes de dos regiones del país. Los factores amabilidad, escrupulosidad e inestabilidad emocional presentan correlaciones estadísticamente significativas con tres dimensiones del CCT. Análisis de regresión lineal revelaron que los cinco rasgos de personalidad contribuyeron para la predicción de las dimensiones del CCT. Los resultados son discutidos con base en la literatura internacional.

Palabras-clave: rendimiento laboral, rasgos de personalidad, cinco grandes factores
\end{abstract}

\section{Introduction}

Currently, the number of researches in Work and Organizational Psychology and in the Psychology of Individual Differences that seek to understand the relationship between personality and job performance has grown (Colbert, Mount, Harter, Witt, \& Barrick, 2004; Fine, Horowitz, Weigler, \& Basis, 2010; Jensen \& Patel, 2011; O’Neill \& Hastings, 2011; Ones \& Viswesvaran, 2001; Rothmann \& Coetzer, 2003; Salgado, 2002). The work performance is seen as the way the employee organizes its work, their capacity for solving problems, time and energy spent in solving the task (Colbert et al., 2004).

Among the studies on work performance, are those that investigate the counterproductive work behaviors
(CWBs), which can be defined as intentional acts that harm the organization and its members (Bennett \& Robinson, 2000; Sackett \& DeVore, 2001; Spector \& Fox, 2005). Different terms are used to refer to CWBs, such as deviant behavior in the workplace (Robinson \& Bennett, 1995), antisocial behavior (Thau, Crossley, Bennett, \& Sczesny, 2007) and counter-productive or counterproductive behavior at work (Omar, Vaamonde, \& Delgado, 2013; Rotundo \& Sacket, 2002), the latter being the most recurrent and used in this study.

There is a wide acceptance of CWBs rated in two dimensions, as suggested by Bennett and Robinson (2000): a) organizational counterproductive behavior (CWB-O) b) interpersonal counterproductive behavior (CWB-I). CWB-Os are seen as intentional actions to harm the organization, such as stealing objects from 
the workplace, sabotage and lack of care for the working environment. CWB-Is are seen as intentional acts towards people in the work environment (colleagues, bosses, subordinates, suppliers, customers), also with the intention to harm them, for example, stealing from coworkers, gossiping, harassing, assaulting physically and verbally, delaying a task to harm a colleague. Robinson and Bennett $(1995,1997)$ state that both these dimensions (CWB-O and CWB-I) are similar in nature, share the same history and house behaviors that vary in severity, ranging from the mildest to the most severe. Thus, studies that have identified high correlations (around 0.80) between these dimensions, have adopted the process of estimating a global score to represent CWB (e.g., Le et al., 2014; Lee \& Allen, 2002), here called CWB-General.

The CWBs can be influenced by situational factors such as job characteristics and the employee perception on payment for the activities developed in the organization (Kelloway, Francis, Prosser, \& Cameron, 2010). However, individual characteristics such as personality traits can also influence employee performance and the manifestation of such behaviors (Colbert et al., 2004; Jensen \& Patel, 2011; Mount et al., 2006; Salgado, 2002).

The assessment of personality traits is a common practice in the organizational context, both in the selection process and in employee development. The results suggest that these factors are associated with job performance in different types of activities (Baumgartl, Nascimento, Patrick, Arvey, \& Krueger, 2009).

Studies such as those of Colbert et al. (2004), Fine et al. (2010), Jensen and Patel (2011) and Salgado (2002) point out the factorial approach of traits as the main line that investigates the personality and as being the one that has offered the most significant contribution to research on CWBs. Thus, in this study the association between personality traits and CWBs will be investigated in the light of the most influential approach of the traits today, which is the Big Five Personality traits - the Five Factor Model - FFM.

In this model, known in Brazil as CGF, five personality traits are identified. They are: neuroticism (low emotional stability, referring to a greater tendency to experience negative emotions), extraversion (sociability or engagement in the outside world), openness to experiences (interest in different areas, tending to originality and imagination), agreeableness (sense of cooperation and social harmony) and conscientiousness (self control and practicality) (Bolton, Baker, \& Barber, 2010; Costa \& McCrae, 2007).
There is a lot of literature on the association between these personality traits and CWBs. We located meta-analysis studies (Berry, Ones, \& Sackett, 2007; Salgado, 2002) as well as empirical studies (Blackman \& Funder, 2002; Colbert et al., 2004; Cullen \& Sackett, 2003; Jensen \& Patel, 2011; Kozako, Safin, \& Rahim, 2013; Mount et al., 2006; Penney, Hunter, \& Perry, 2011).

Salgado conducted a meta-analysis study to verify whether the Big Five would be predictors of counterproductive behavior, absenteeism, accidents and turnover. On CWBs in general, the results showed that Conscientiousness and Agreeableness could be considered valid predictors of CWBs (validity coefficients -0.16 and -0.13 , respectively). Neuroticism, openness to experience and extraversion showed weak validity coefficients (-0.04, 0.10 and 0.01 , respectively). Similar results were found in the meta-analysis conducted by Berry et al. (2007). Higher correlation was identified between CWBs and conscientiousness ( $\varrho=-0.42$ ), agreeableness $(\varrho=-0.46)$ and neuroticism $(\varrho=-0.27)$. Extraversion and openness to experience had low correlations with CWBs ( $\varrho$ ranging from -0.09 to 0.02). The authors also found that agreeableness best predicts CWB-I, while conscientiousness predicts CWB-O.

An example of empirical research is a study conducted by Mount et al. (2006) with 141 employees, CWB-O was more strongly associated with conscientiousness $(r=-0.55)$, while CWB-I was more strongly associated with agreeableness $(r=-0.48)$. Kozako et al. (2013), based on a sample of 178 employees in the hotel industry, also investigated the influence of personality traits of the Big Five model on the CWB-O and CWB-I dimensions. As a result, agreeableness $(\beta=-0.41, p<$ 0.01 ), neuroticism $(\beta=0.32, p<0,01)$ and openness $(\beta=0.13, \mathrm{p}<0.10)$ were predictors of CWB-O. Considering the CWB-I scale, neuroticism $(\beta=0.26, p<$ $0.01)$, openness $(\beta=0.21, p<0.01)$, extraversion $(\beta=$ $-0.19, p<0,10)$ and agreeableness $(\beta=0.46, \mathrm{p}<0.01)$ remained in the prediction model. Unlike the findings of previous studies, the conscientiousness factor was not associated with any of the dimensions of CWB.

For better understanding of the CWB history, individual and situational variables have been included along with five personality factors. As an example of situational variable we can cite perception of justice. O’Neill, Lewis and Carswell (2011) included perception of Distributive Justice (how well the employee feels financially rewarded for their service to the organization) in addition to the Big Five model of personality 
factors to investigate if all these variables would be predictive of CWBs. 464 employees working in a large retail company participated in this study. Associations between the conscientiousness, agreeableness and neuroticism factors and CWBs were of greater magnitude $(r=-0.47, r=-0.33$ and $\mathrm{r}=0.26$, respectively) than the association between perceived distributive justice and CWBs $(\mathrm{r}=-0.12)$. When considering CWB-I and $\mathrm{CWB}-\mathrm{O}$, the regression analysis indicated that the conscientiousness (CWB-I: $\beta=-0.31$; CWB-O: $\beta=-0.43$, $p<0.05$ ), agreeableness (CWB-I: $\beta=-0.17$; CWBO: $\beta=-0.03, p<0.05$ ) and neuroticism (CWB-I: $\beta=$ 0.04; CWB-O: $\beta=0.08, p<0.05)$ personality factors performed better as explanatory variables for the counterproductive behavior than perceptions of distributive justice at work (CWB-I: $\beta=-0.01$; CWB-O: $\beta=-0.03$, $p<0.05)$.

Another example of situational variable investigated along with the Big Five and CWB model is job satisfaction. In recent literature, we should highlight the study conducted by Le et al. (2014), since it is a longitudinal study. Approximately 400 teenagers from 451 families in the project entitled Iowa Youth and Families Project that had results with the abbreviated version of NEO PI-R (NEO-FFI, Costa \& MacCrae, 2007) collected in the years 1991 and 1992 were invited to answer the Workplace Deviance Scale -WDS (Bennett \& Robinson, 2000) and a general question about job satisfaction in the years 2007 and 2010. Scores on academic performance were also analyzed. Through correlation and mediation analysis, the authors found that the agreeableness and conscientiousness factors assessed during the adolescence were significantly correlated with CWB-General (-0.18 in both factors), CWB-O (-0.12 and - 0.16, respectively) and CWB-I $(-0.20$ and -0.16 , respectively). Although significant correlations between CWBs and job satisfaction have been identified (between -0.14 and -0.18), the inclusion of this variable as a mediator did not substantively alter the associations between personality traits and CWBs.

Along with the factors of the Big Five model, dysfunctional or pathological personality traits have also been investigated as predecessors of CWB (e.g.: DeShong, Grant, \& Mullins-Sweatt, 2015; Penney \& Spector, 2002; Wu \& Lebreton, 2011). Among these studies we highlight the latest from DeShong and colleagues who examined through path analysis whether the Big Five model or the Dark Triad model (Machiavellianism, narcissism and psychopathy) could better predict CWB. Based on a sample of 163 student workers, they found that the model with better fit and most parsimonious was the personality one, and that the conscientiousness and agreeableness factors, both for CWB-I and for CWB-O, were the most important predictors.

Therefore, one can assume that the Big Five model has been dominant in the study of individual records for engagement in counterproductive behaviors in the workplace. Among the personality traits, two factors have significant associations with this behavior, indicating that low conscientiousness and agreeableness may indicate increased vulnerability to involvement in counterproductive behavior at work.

Although the importance of the research associating these two constructs is well established, one can understand that it is relevant to accumulate evidence on what traits of the Big Five model influence the CWB. Derived empirical results in the Brazilian context may contribute to the generalization of findings from other cultures. Thus, in accordance with international studies, in this study we sought to identify whether and which Big Five model of personality factors are associated with CWBs and contribute to explain the involvement of workers in such behavior.

\section{Method}

\section{Participants}

381 professionals participated in this study: 142 residents in cities of Minas Gerais and 239 in cities of Bahia. Of the total sample, $74.3 \%$ were female, and the age of the participants ranged from 18 to 69 years (mean $=30.42, S D=8.47)$. There was a higher share of graduates (primary school $=0.3 \%$; high school $=35.4 \%$; higher education $=64.3 \%$ ). All had been formally employed for at least one year, occupying different hierarchical levels. The sample came from organizations of different sizes $($ micro $=12.0 \%$; small $=25.7 \%$; medium $=16.6 \%$ and large $=45.7 \%$ ). Regarding the type of organization, $21.6 \%$ worked in industry and $77.4 \%$ in commerce and services, and among the services, $43.3 \%$ worked in education.

\section{Instruments}

A) NEO-PI-R, by Costa and McCrae (2007), with 240 items. This test measures the five personality dimensions, namely: Neuroticism, Extraversion, Openness to experience, Agreeableness and Conscientiousness. These five dimensions are subdivided, resulting in 30 facets (six for each). The test consists of 240 items, 
which are answered on a Likert scale of five points ranging from 1 (strongly disagree) to 5 (strongly agree). The assessment time is free, with estimated duration of about 60 minutes. The study of adaptation, validation and standardization of the NEO PI-R for Brazil was completed in 2007. The psychometric analysis through internal consistency (Cronbach's alpha) showed that all coefficients were satisfactory with $\alpha=0.80$ for the factors (Costa \& McCrae, 2007).

B) To assess the counterproductive behavior we used the Workplace Deviance Scale (WDS) developed by Bennett and Robinson (2000) with 19 items that assess directly two broad areas of counterproductive behavior in the workplace. The scale contains 12 items that assess the counterproductive behavior prejudicial to the organization, such as, "Falsified a receipt to get reimbursed for more money than you spent on business expenses". The remaining seven items assessed counterproductive behavior prejudicial to the work with peers, such as "Acted rudely toward someone at work." The response scale is Likert with seven options ("never" = 1 point, "once" $=2$ points, "twice" $=3$ points, "several times" = 4 points, "monthly" $=5$ points, "weekly" $=6$ points and "daily" $=7$ points). To calculate the scores for each type of CWB, i.e., CWB-I and CWB-O, the scores must be added up in the corresponding items of each type (maximum values of 49 and 84, respectively). The scale's psychometric evidence, as provided by the authors of the original version, showed an alpha coefficient of 0.81 for the scale of organizational deviation and 0.78 for interpersonal deviation scale. Although the original version did not intend to obtain a general score, in line with international studies (e.g., Lee \& Allen, 2002) that were carried out, we chose to adopt this procedure. Thus, the total score is obtained by the sum of the responses to the 19 items (ranging from zero to 133 points). This scale was adapted for use in Brazil (Andrade, Mendonça, Coutinho, \& Nascimento, 2011; Coutinho, Ferreira, Andrade, \& Nascimento, 2013), being entitled WDS-BR.

C) Demographic questionnaire to obtain the data on the professional and personal profile of the participants, such as gender, age, education, function, position held within the company, size of the organization. These variables were used in the descriptive analysis of the study.

\section{Data Collection Procedures}

Data collection occurred in the participants' workplace and two of Minas Gerais colleges. The scales were applied collectively in formal workers with (at least) high school education and also college students with a formal job.

A previous contact was made with the companies and colleges to explore the interest and availability of the subjects to participate in the survey, since the application of the instruments would be held in the workplace. Thus, it was necessary to put together a working schedule that did not affect the routine of the company. In the colleges, teachers made their class hours available for the collection procedures. In all companies and colleges, dates and hours were scheduled for the work with the instruments. At the time of application of the instruments, all participants were informed on the objectives of the study, on the anonymity of your answers, explaining that there was no identification on the answer sheets. They were asked to sign an informed consent form, in which the researchers' commitment to secrecy was emphasized.

Participants were informed that the data would be analyzed in groups rather than individually, and that the individual feedback on the results was not possible. The application of the instruments was divided into two sessions, the first session with the personality test NEO PI-R, and the second session with the following scales: WDS, CPI-Cp and demographic questionnaire. Every application was made by one of the authors with the aid of undergraduate students. The average application time was three hours. All ethical aspects required in relation to the participants were respected; the Ethics Committee approved the research.

\section{Data Analysis Procedures}

To investigate the association between CWB variables and personality traits; Pearson correlation techniques and linear regression analysis were used. Specific regression models were estimated for each of the dependent variables (CWB-General, CWB-O and CWB-I).

For estimation of the regression models, initially, all independent variables were included, in this case the five personality factors, and the forward procedure was used to select the variables that would remain in the final model. For this, each independent variable was removed sequentially, one by one, that had not provided a significant contribution to the prediction variable, depending on the criterion of the largest p-value. As a cutoff criterion, we used a level of significance greater than 0.05 and a new model was estimated with the rest of the independent variables. This procedure was repeated, 
and the estimation process of the final model was completed with all the independent variables that remained in the model and met the criterion of significance.

\section{Results}

The results indicated weak to moderate correlations between personality factors and CWBs (Table 1). The correlations with CWB-General varied between 0.07 (extraversion) and -0.41 (agreeableness). Of the five personality factors, only extraversion showed no significant association. Regarding the considered CWB dimensions, the pattern of correlations for CWB-O was similar to the CWB-General, in which the correlations ranged from 0.04 (extraversion) and 0.38 (conscientiousness). In regard to CWB-I, among the correlation coefficients (ranging from 0.04 to -0.35 ), the agreeableness, conscientiousness and neuroticism factors showed the most significant coefficients, from a statistical point of view.

In order to investigate whether the personality factors are predictors of CWBs, adjusted linear regression models (forward procedure) were obtained for each of the WDS scores (CWB-General, CWB-O and CWBI). The early models were comprised of the following independent variables: neuroticism, extraversion, openness, agreeableness and conscientiousness. Table 2 shows the final models.

In the regression model of the overall score in the WDS-BR, the adjusted R2 value (0.25) indicated that, together, the scores of neuroticism, openness, agreeableness and conscientiousness factors explained $25 \%$ of the variation observed in the CWB-General score with standardized regression coefficients ranging from -0.29 to 0.02 . The final regression model with the CWB-O factor was composed of the neuroticism, openness, agreeableness and conscientiousness factors. The adjusted $\mathrm{R} 2$ value (0.24) indicated that, together, these factors explained about $24 \%$ of the variation observed in the CWB-O score, with standardized regression coefficients ranging between -0.24 and 0.04 . The standardized regression coefficient indicates that the agreeableness factor is stronger when compared to other personality factors to predict CWB-O. The final regression model with the CWB-I factor was composed of the independent variables, extraversion and agreeableness. The adjusted value of R2 (0.13) indicated that, together, the scores of the variables extraversion and agreeableness explained about $13 \%$ of the variation observed in the CWB-I score, with standardized regression coefficients ranging between -0.33 and 0.00 . In this case, the agreeableness factor was presented as the best predictor of CWB-I.

\section{Discussion}

Considering the growing interest in investigating background variables that can predict counterproductive behavior at work, this study sought to contribute to the survey of empirical evidence on the role of individual characteristics, in particular, personality factors, of such behaviors. Whereas the main aspect that characterizes CWB is the intention behind the action, it is understood that personality can potentially influence the engagement in such behaviors.

To this end, personality factors of the Big Five model were considered. This choice was based in the finding that this has been the most widely used model worldwide to investigate the role of individual characteristics in different contexts.

This study provides additional evidence that personality traits and CWBs are related. It was observed that the agreeableness, conscientiousness, and neuroticism factors, associated with a greater magnitude CWB-General, as reported by Salgado (2002), Berry et al (2007) and Pankaj and Patel (2011).

Table 1

Pearson Correlation Coefficients between the Big Five Personality Factors and CWBs

\begin{tabular}{lccccc}
\hline WDS-BR & neuroticism & extraversion & openness & agreeableness & conscientiousness \\
\hline CWB-general & $0.32^{* *}$ & 0.07 & $0.14^{* *}$ & $-0.41^{* *}$ & $-0.36^{* *}$ \\
CWB-O & $0.36^{* *}$ & 0.04 & $0.15^{* *}$ & $-0.36^{* *}$ & $-0.38^{* *}$ \\
CWB-I & $0.12^{*}$ & 0.09 & 0.04 & $-0.35^{* *}$ & $-0.21^{* *}$ \\
$n=381$ & & & & & \\
\hline
\end{tabular}

Note. $* p<0.05 ; * * p<0.01$.

Psico-USF, Bragança Paulista, v. 21, n. 3, p. 677-685, set./ dez. 2016 
Table 2

Multiple Linear Regression Models for the CWBs

\begin{tabular}{llccccc}
\hline D.V. & Factors & $\beta$ & S.D. & S.C. & $\mathrm{t}$ & T.R. \\
\hline CWB-general & (Constant) & 68.79 & 7.54 & & $9.13^{*}$ & 53.97 a 83.6 \\
& Neuroticism & 0.07 & 0.03 & 0.14 & $2.69^{*}$ & 0.02 a 0.13 \\
& Openness & 0.11 & 0.03 & 0.17 & $3.76^{*}$ & 0.05 a 0.17 \\
& Agreebleness & -0.22 & 0.04 & -0.29 & $-5.85^{*}$ & -0.29 a -0.14 \\
& Conscienciousness & -0.09 & 0.03 & -0.16 & $-3.02^{*}$ & -0.15 a -0.03 \\
CWB-O & (Constant) & 60.51 & 7.81 & & $7.75^{*}$ & 45.15 a 75.86 \\
$(n=364)$ & Neuroticism & 0.10 & 0.03 & 0.19 & $3.55^{*}$ & 0.04 a 0.15 \\
& Openness & 0.11 & 0.03 & 0.17 & $3.67^{*}$ & 0.05 a 0.18 \\
& Agreebleness & -0.16 & 0.04 & -0.22 & $-4.17^{*}$ & -0.24 a -0.08 \\
& Conscienciousness & -0.10 & 0.03 & -0.18 & $-3.21^{*}$ & -0.16 a -0.04 \\
CWB-I & (Constant) & 75.05 & 5.46 & & $13.73^{*}$ & 64.30 a 85.79 \\
$(n=364)$ & Extraversios & 0.06 & 0.03 & 0.10 & $2.15^{*}$ & 0.00 a 0.12 \\
& Agreeableness & -0.26 & 0.04 & -.035 & $-7.22^{*}$ & -0.33 a -0.19 \\
\hline
\end{tabular}

Notes. DV = Dependent Variable; SD = Standard Deviation; SC = Standardized Coefficient; ${ }^{*} p<0.001$; TR $=$ Trustworthy Range. CWB-general: $\mathrm{R}^{2}=0.250$; CWB-O: $\mathrm{R}^{2}=0.241$; CWB-I: $\mathrm{R}^{2}=0.134$.

Given the scientific and social interest in understanding factors that may influence the expression of certain behaviors, we used regression analysis to investigate whether the personality factors in the Big Five model predicted CWBs. Thus, we obtained linear regression models that were adjusted for the scores of each dimension of CWB, as assessed through the WDS-BR. The models for CWB-General and CWB-O were very similar when pointing out that, together; neuroticism, openness, agreeableness and conscientiousness are predictors of such behavior. The final regression model for CWB-I was composed of the extraversion and agreeableness factors. In all three models the greatest contribution was that of agreeableness.

These results indicate, therefore, that employees who present themselves as highly conscientious in relation to planning, organizing and conducting tasks and also agreeable, more predisposed to sympathize with situations that relate to others are less likely to show CWBs. In the case of the Neuroticism factor, lower score on this factor suggests better emotional adjustment, ability to control impulses and stress (Costa \& McCrae, 2007). Thus, employees who have low scores on neuroticism were therefore less likely to engage in counterproductive behavior both facing the organization and co-workers (Pankaj \& Patel, 2011).

The analysis of predictive models reported in the literature (DeShong, Grant \& Mullins-Sweatt, 2015; Kozako et al., 2013; Le et al., 2014; O’Neill et al., 2011) show variations on what factors are predictors of CWBs. In the predictive models analyzed, the factors conscientiousness and agreeableness are present. The finding in the study by Kozako et al. that the conscientiousness factor was not a predictor of CWBs is an exception. In this study, it also stands out that, in addition to neuroticism and agreeableness, the openness factor was a predictor of CWB-O and extraversion of CWB-I. The identification of openness and extraversion as predictor variables of CWBs coincides with the results of this study.

\section{Final Considerations}

The results of this study reinforce the importance of investigating the association between personality traits and CWBs and, in particular, the applicability of the Big Five model for understanding the factors that influence engagement in such behaviors. As reported in the literature, from the personality factors in this model, 
agreeableness was identified as the best predictor for both the general construct as well as the dimensions that indicate the direction of intentional actions, being those related to the organization and/or to the actors involved in it.

Some limitations of this study should be mentioned. The first refers to the fact that the results were generated from a non-probability sample from two regions of Brazil. Thus, we recommend that future studies should include workers from other regions, endeavoring effort to achieve probability samples. A second limitation to be highlighted is that only one variable was considered. We recommend that further investigations in other individual and environmental factors are also added to the research outline, in order to better capture what background factors are involved in CWBs, and which variables have mediating or moderating role.

In order to deepen the links between personality traits and CWBs, future studies could be developed exploring the facets that make up each of the five personality factors on the model of Costa and McCrae (2007). Also, we recommend that research be conducted in organizational environments using external criteria, such as peer and managerial reviews and performance evaluations.

\section{References}

Andrade, J. E., Mendonça, L. M. M. M., Coutinho, A. C. A. M., \& Nascimento, E. (2011). Workplace Deviance Scale (WDS) para o contexto brasileiro. In: $V$ Congresso Brasileiro de Avaliação Psicológica. Anais do V Congresso Brasileiro de Avaliação Psicológica, Bento Gonçalves, Brasil.

Baumgartl, V. O., Nascimento, E., Patrick, C., Arvey R., \& Krueger, R. (2009). Integridade e externalização: Estudo exploratório em uma amostra de estudantes de psicologia. Psico-USF, 14(3), 299-308.

Bennett, R. J., \& Robinson, S. L. (2000). Development of a measure of workplace deviance. Journal of $A p$ plied Psychology, 85, 349-360.

Berry, C. M., Ones, D. S., \& Sackett, P. R. (2007). Interpersonal deviance, organizational deviance, and their common correlates: A review and meta-analysis. Journal of Applied Psychology, 92, 410-424.

Blackman, M. C., \& Funder, D. C. (2002). Effective Interview Practices for Accurately Assessing
Counterproductive Traits. International Journal of $S_{e-}$ lection and Assessment, 10(1/2), 109-116.

Bolton, L. R., Becker, L. K., \& Barber, L. K. (2010). Big Five trait predictors of differential counterproductive work behavior dimensions. Personality and Individual Differences, 49(5), 537-541.

Coutinho, A. C. M., Andrade, J. E., Ferreira, M. F., \& Nascimento, E. (2013). Análise psicométrica da versão adaptada da Workplace Deviance Scale - WDS. In VI Congresso Brasileiro de Avaliação Psicológica e IX Congreso Iberoamericano de Diagnóstico y Evaluación Psicológica. Anais do VI Congresso Brasileiro de Avaliação Psicológica, IX Congreso Iberoamericano de Diagnóstico y evaluación psicológica, Macéio/AL, Brasil.

Costa, P. T., Jr., \& McCrae, R. R. (2007). Inventário de personalidade neo revisado e inventário de cinco fatores neo revisado NEO-FFI (versão curta). $1^{a}$ ed. São Paulo: Vetor.

Cullen, M. J., \& Sackett, P. R. (2003). Personality and counterproductive workplace behavior. In M. R. Barrick \& A. M. Ryan. Personality and Work: Reconsidering the Role of Personality in Organizations. San Francisco: Jossey-bass.

Colbert, A. E., Mount, M. K., Harter, J. K., Witt, L. A., \& Barrick, M. R. (2004). Interactive Effects of Personality and Perceptions of the Work Situation on Workplace Deviance. Journal of Applied Psychology, 89(4), 599-609.

DeShong, H. L, Grant, D. M., \& Mullins-Sweatt, S. N. (2015). Comparing models of counterproductive workplace behaviors: The Five-Factor model and the Dark Triad. Personality and Individual Differences, $74,55-60$.

Fine S., Horowitz, I., Weigler, H., \& Basis, L. (2010). Is good character good enough? The effects of situational variables on the relationship between integrity and counterproductive work behaviors. Human Resource Management Review, 20, 73-84.

Hakstian A. R., Farrell S., \& Tweed R. G. (2002). The assessment of counterproductive tendencies by means of the California Psychological Inventory. International Journal of Selection and Assessment, 10, 58-86.

Jensen, J. M., \& Patel. P. C. (2011). Predicting counterproductive work behavior from the interaction of 
personality traits. Personality and Individual Differences, 51, 466-471.

Kelloway, E. K., Francis, L., Prosser, M., \& Cameron, J. E. (2010). Counterproductive work behavior as protest. Human Resource Management Review, 20, 1, 18-25.

Kozako, I. N. A. M. F., Safin, S. Z., \& Rahim, A. R. A. (2013). The Relationship of Big Five Personality Traits on Counterproductive Work Behavior among Hotel Employees: An Exploratory Study. Procedia Economics and Finance, 7, 181-187.

Le, K., Donnellan, M. B, Spilman, S. K, Garcia, O.P., \& Conger, R. (2014). Workers behaving badly: associations between adolescent reports of the Big Five and conuterproductive work behaviors in adulthood. Personality and Individual Differences, 6162, 7-12.

Lee, K., \& Allen, N. J. (2002). Organizational citizenship behavior and workplace deviance: the role of affect and cognitions. Journal of Applied Psychology, 87(1), 131-142.

Mount, M., Ilies, R., \& Johnson, E. (2006). Relationship of Personality Traits and Counterproductive work Behaviors: The mediating effects of Job Satisfaction. Personnel Psychology, 59, 591-622.

Omar, A., Vaamonde, J. D., \& Delgado, H. U. (2013). Comportamientos contraproducentes en el trabajo: diseño y validación de una escala. Diversitas, 8(2), 249-265.

Ones, D. S. (2002). Introduction to the special issue on counterproductive behaviors at work. International Journal of Selection and Assessment, 10(1), 1-4.

O’Neill, T. A., \& Hastings, S. E. (2011). Explaining workplace deviance behavior with more than just the "Big Five". Personality and Individual Differences, 50, 268-273.
O’Neill, T. A., Lewis, R. J., \& Carswell, J. J. (2011). Employee personality, justice perceptions, and the prediction of workplace deviance. Personality and individual differences, 51(5), 595-600.

Pankaj M. J., \& Patel, C. (2011). Predicting counterproductive work behavior from the interaction of personality traits. Personality and Individual Differences, 51, 466-471.

Penney, L. M., Hunter, E. M., \& Perry S. J. (2011). Personality and counterproductive work behavior: Using conservation of resources theory to narrow the profile of deviant employees. Journal of Occupational and Organizational Psychology, 84, 58-77.

Rothmann, S., \& Coetzer, E. P. (2003). The Big Five Personality Dimensions And Job Performance. Journal of Industrial Psychology, 29(1), 68-74.

Penney, L. M., \& Spector, P. E. (2002). Narcissism and counterproductive work behavior: Do bigger egos mean bigger problems? International Journal of selection and Assessment, 10(1-2), 126-134.

Robinson, S., \& Bennett, R. (1995). A typology of deviant workplace behaviors: A multi-dimensional scaling study. Academy of Management Journal, 38, 555-572.

Robinson, S., \& Bennett, R. (1997). Workplace deviance: Its definition, its manifestations, and its causes. Research on Negotiations in Organizations, 6, 3-27.

Salgado, J. F. (2002). The Big Five personality dimensions and counterproductive behaviors. International Journal of Selection and Assessment, 10, 117-125.

Wu, J., \& Lebreton, J. M. (2011). Reconsidering the dispositional basis of counterproductive work behavior: the role of aberrant personality. Personnel Psychology, 64, 593-626.

$1^{a}$ Reformulação 09/02/2015

$2^{a}$ Reformulação 18/08/2015

Aceito 27/10/2015 
Nota das autoras:

Apoio institucional: Laboratório de Avaliação das Diferenças Individuais (LADI) do Departamento de Psicologia/ UFMG

Sobre as autoras:

Mônica Freitas Ferreira Novaes: Psicóloga. Especialista em avaliação e diagnóstico psicológico pela PUC-MG. Mestre em psicologia do desenvolvimento humano pela UFMG. Professora de Graduação do curso de Psicologia do Centro Universitário Newton Paiva e da Faculdade de Pará de Minas (FAPAM).

E-mail:monica.freitas.ferreira@gmail.com

Elizabeth do Nascimento possui graduação em Psicologia pela Universidade Federal de Minas Gerais (1987), mestrado em Psicologia pela Universidade Federal de Minas Gerais (1993) e doutorado em Psicologia pela Universidade de Brasilia (2000). Professora associada da Universidade Federal de Minas Gerais e atualmente vice-coordenadora do Programa de Pós-graduação em Psicologia da UFMG(2014-2016). Tem experiência na área de Psicologia, com ênfase em Construção e Validade de Testes, Escalas e Outras Medidas Psicológicas, atuando principalmente nos seguintes temas: inteligência, personalidade, WAIS-III, psicometria, avaliação psicológica, envelhecimento. Recentemente tem se dedicado a temas em saúde ocupacional. É pesquisadora CNPq.

E-mail: bethdonascimento@gmail.com

Contato com as autoras:

Rua Gomes Freire, 54/201 - Jardim Atlântico

CEP: $31555-170$

Belo Horizonte-MG, Brasil

Telefones: (31) 3785-2148/ (31) 98842-7521.

E-mail: monica.freitas.ferreira@gmail.com 